\title{
INTERNALISASI SIKAP KEBERAGAMAAN SEJAK ANAK USIA DINI
}

\author{
Ismail dan Fahmi \\ (Dosen Tetap Fakultas Ilmu Tarbiyah dan Keguruan UIN Raden Fatah Palembang)
}

\begin{abstract}
Abstrak
Anak di usia dini merupakan bagian yang sangat berharga, oleh karena itu diistilahkan dengan masa keemasan (golden age), masa ini tidak akan terulang untuk kedua kalinya. Tulisan ini membahas mengenai bagaimana internalisasi sikap keberagamaan yang harus kita berikan sejak anak berusia dini (usia 0-6 tahun). Karena dalam usia ini, kita dapat menanamkan nilai-nilai keimanan (tauhid), nilai ibadah dan juga nilai-nilai akhlak. Nilai-nilai tersebut jika diinternalisasikan sejak anak berusia dini, maka akan menjadi bekal bagi pertumbuhan dan perkembangan anak kelaknya. Karena nilai-nilai tersebut dapat membentuk sikap keberagamaan yang sesuai dengan nilai-nilai dasar Islam. Pendidikan Islam mampu melahirkan sikap keberagamaan dalam diri anak sejak usia dini, jika diinternalisasikan secara berkelanjutan. Karena pendidikan Islam merupakan sistem pendidikan yang menuntut untuk melatih anak didik agar memiliki nilai dan kepribadian yang sesuai dengan tuntutan agama.
\end{abstract}

\section{Kata Kunci: Internalisasi, Sikap Keberagamaan, Anak Usia Dini}

\section{Pendahuluan}

Pindidikan terhadap anak usia dini merupakan bagian yang penting dan harus mendapatkan perhatian yang intensif, karena anak dalam usia ini merupakan masa keemasan (golden age) yang hanya terjadi satu kali dalam perkembangan usia anak. Dalam usia ini anak harus mendapat perhatian yang baik. Murdiono (2009:3) mengemukakan bahwa jika anak dalam usia ini kurang mendapatkan perhatian dalam hal pendidikan, perawatan, pengasuhan dan layanan kesehatan serta kebutuhan gizinya dikhawatirkan anak tidak dapat tumbuh dan berkembang secara optimal.

Untuk mempersiapkan sumber daya yang berkualitas di masa yang akan datang, pendidikan merupakan salah satu hal yang penting yang dapat diberikan sejak dini, karena anak adalah investasi masa depan. Oleh karena itu, pendidikan yang dilakukan harus diawasi dan dipelihara secara berkelanjutan sebagai bentuk pelatihan dasar agar anak memiliki potensi berkembang secara optimal dalam setiap perkembangannya. 
Jalaluddin Rahmat (1995:204)

mengemukakan, bahwa dalam membentuk sikap, prilaku dan kebiasaan anak yang baik, agama memiliki peran yang sangat besar. Pendidikan Islam membentuk sedemikian rupa sehingga dalam sikap hidup, tindakan, dan pendekatannya dalam segala jenis pengetahuan banyak dipengaruhi oleh nilai-nilai spiritual dan sangat sadar akan nilai etika Islam (Abdurahman, 1992:187).

Agama sangat berperan dalam pembentukan prilaku anak, sehingga pembentukan prilaku anak akan membaur sesuai dengan pertumbuhan dan perkembangan anak. Sehingga diperlukan pendidikan dengan persyaratan-persyaratan tertentu dan pengawasan serta pemeliharaan yang terus-menerus. Kemudian pelatihan dasar dalam pembentukan kebiasaan dan sikap memiliki kemungkinan untuk berkembang secara wajar dalam kehidupan di masa mendatang (Jalaluddin Rahmat, 1995:204).

Agar poses pembentukan prilaku dapat berjalan dengan baik, penerapan pendidikan nilai Islam untuk anak usia dini harus melibatkan seluruh elemen yang menunjang iklim sekolah, sehingga terjadi interaksi positif antara peserta didik dengan nilai-nilai yang akan diinternalisasikan (Wahyudi, 2005:28). Peranan pendidik di sini sebagai teladan (role model) dalam pembelajaran.

Pendidikan jika diberikan sejak anak usia dini, dan dimulai dari dasar iman kepada Allah SWT, takut kepada-Nya, meminta tolong dan berserah diri hanya kepada-Nya, niscaya akan mempunyai kemampuan fitri dan tanggapan naluri untuk menerima setiap keutamaan dan kemulian, dan akan terbiasa dengan akhlak mulai (Ulwan, 1990:169). Dengan dasar keimanan kepada Allah SWT tersebut anak sejak usia dini mampu melakukan latihan-latihan beragama, sehingga nantinya mereka dapat merasakan manisnya beribadah. Dengan begitu anak akan mampu mempunyai sifat dan sikap terpuji, karena untuk memiliki sifat dan sikap yang terpuji tidak mungkin dengan penjelasan saja, melainkan perlu pembiasaan yang terus-menerus dilakukan.

Pendidikan Islam mampu melahirkan sikap keberagamaan dalam diri anak sejak usia dini, jika diinternalisasikan secara berkelanjutan. Karena pendidikan 
Islam merupakan sistem pendidikan yang menuntut untuk melatih anak didik agar memiliki nilai dan kepribadian yang sesuai dengan tuntutan agama. Penerapan pendidikan Islam pada anak usia dini harus melibatkan seluruh elemen yang menunjang iklim lingkungan pendidikan, agar terjadi interaksi positif antara peserta didik dengan nilai-nilai yang akan diinternalisasikan.

Salah satu bagian penting yang harus mendapatkan perhatian terkait dengan pendidikan yang diberikan sejak usia dini adalah internasilasi sikap keberagamaan. Dengan Internalisasi sikap keberagamaan sejak anak usia dini, diharapkan dalam proses selanjutnya anak akan mampu membedakan baik buruk, benar salah, sehingga ia dapat menerapkannya dalam kehidupan sehari-hari.

\section{Sikap Keberagamaan Peserta didik}

Untuk lebih memahami mengenai sikap keberagamaan peserta didik, dalam kesempatan ini terlebih dahulu saya akan membahas secara singkat mengenai hakikat sikap, hakikat agama dan kemudian membahas mengenai sikap keberagamaan yang dimaksud dalam penelitian ini.

\section{Hakikat Sikap}

Secara historis istilah sikap digunakan pertama kali oleh Herbert Spencer tahun 1862 yang pada saat itu diartikan olehnya sebagai status mental seseorang (Saifuddin Azwar, 2009:3). Pada tahun 1888 Langge menggunakan istilah sikap dalam eksperimen mengenai respons untuk menggambarkan kesiapan subyek dalam menghadapi stimulus yang datang tiba-tiba. Menurut Lange Sikap tidak hanya merupakan aspek mental semata melainkan mencakup pula aspek respon fisik (Saifuddin Azwar, 2009:4).

Dalam kamus bahasa Indonesia, sikap didefinisikan sebagai berikut: sikap adalah perilaku, gerak dan gerik, atau perbuatan yang berdasarkan pada pendirian (pendapat atau keyakinan). Menurut Ngalim Purwanto (1990:141), Sikap atau yang dalam bahasa Inggris disebut attitude adalah suatu cara bereaksi terhadap suatu perangsang; suatu kecenderungan untuk bereaksi dengan cara tertentu terhadap suatu perangsang atau situasi yang terjadi. 
Sikap pada awalnya diartikan sebagai suatu syarat untuk munculnya suatu tindakan (2008:45). Selanjutnya Masri dalam Zaim Elmubarok (2008:45), mengartikan sikap sebagai kesediaan yang diarahkan untuk menilai atau menanggapi sesuatu. Allfort dalam Zaim Elmubarok (2008:45), mendefinisikan sikap adalah keadaan siap (presdisposisi) yang dipeserta didiki untuk merespon obyek tertentu yang secara konsisten mengarah pada arah yang mendukung (favorabel) atau menolak (unfavorable). Tampaknya definisi tadi sependapat dengan yang dikemukakan oleh pakar psikologi, seperti Louis Thurstone, Rensis Likert dan Charles Osgood. Menurut mereka sikap seseorang terhadap suatu obyek adalah perasaan mendukung atau memihak (favorable) maupun perasaan tidak mendukung atau tidak memihak (unfavorable) terhadap obyek tersebut (Saifuddin Azwar, 2009:5).

Selanjutnya sikap diartikan sebagai suatu presdiposisi atau kecenderungan yang relative stabil dan berlangsung terus menerus untuk bertingkah laku atau mereduksi dengan cara tertentu terhadap pribadi lain, obyek atau lembaga, atau persoalan tertentu (JP. Chaplin, 2004:43). Morgan mendefinisikan sikap sebagai sikap ekspresi sederhana terhadap seberapa banyak kita suka atau tidak suka pada berbagai hal. Kemudian dijelaskan bahwa obyek sikap dapat berupa benda yang benarbenar ada (seperti; restoran, masjid dan sekolah), orang (seperti: teman baik, diri sendiri, guru), atau konsepkonsep abstrak (seperti: hukum perdata) (Clif T. et all, 1987:382).

Kemudian attitude dapat juga diterjemahkan dengan sikap terhadap obyek tertentu yang dapat merupakan sikap pandangan atau sikap perasaan tetapi sikap tersebut disertai dengan kecenderungan untuk bertindak sesuai dengan obyek itu. Jadi attitude bisa diterjemahkan dengan tepat sebagai sikap dan kesediaan beraksi terhadap suatu hal. Attitude mengkin terarahkan pada benda-benda, orang-orang, tetapi juga peristiwa-peristiwa, pemandangan-pemandangan,

lembaga-lembaga, norma-norma, nilai-nilai dan lain-lain (Gerungan, 2004:160). Attitude dapat dibedakan menjadi: Attitude sosial yaitu suatu attitude dinyatakan dengan cara-cara kegiatan yang sama dan berulang- 
ulang terhadap suatu obyek sosial, dan biasanya attitude sosial dinyatakan tidak hanya oleh seseorang tetapi juga oleh orang lain yang sekelompok atau masyarakat, misalnya penghormatan sekelompok orang terhadap bendera. Kedua, attitude individual yang terdiri atas kesukaan dan ketidaksukaan pribadi atas obyek, orang, binatang dan hal-hal tertentu (Gerungan, 2004:161-162).

G.W. Allport mengemukakan bahwa sikap adalah keadaan mental dan saraf dari kesiapan, yang diatur melalui pengamatan yang memberikan pengaruh dinamik atau terarah terhadap respon individu pada semua obyek dan situasi yang berkaitan dengannya (David O, Sears dkk, 1994:137). Definisi ini sangat dipengaruhi oleh tradisi mengenai belajar, juga ditekankan bagaimana pengalaman masa lalu membentuk sikap. Dengan alasan yang sama, sikap terutama digambarkan sebagai kesiapan untuk selalu menanggapi dengan cara tertentu dan menekankan implikasi perilakunya.

Dari beberapa pengertian di atas, dapat disimpulkan bahwa sikap manusia adalah suatu bentuk reaksi perasaan seseorang terhadap suatu obyek. Sikap itu berupa yang mendukung (favorable) maupun perasaan tidak mendukung (unfavorable) yang mempunyai tiga komponen yaitu: kognitif, afektif dan behavioral.

Dengan demikian perubahan prilaku ditentukan oleh perubahan sikap terhadap sesuatu. Artinya, untuk mengubah arah atau mengarahkan perilaku seseorang mesti mengubah dulu sikapnya. Sikap selalu didahului oleh keyakinan terhadap subyek yang ditanggapi. Hal ini dikarenakan sikap berkaitan dengan sistem nilai yang dianut seseorang akan menjadikannya sebagai central value dalam menentukan sikap pada seseorang terhadap sesuatu. Oleh karena itu, ada yang merumuskan sikap sebagai organization of belief (Robert S. Fieldman, 2000:11). Pengorganisasian keyakinan ini menggambarkan obyek atau situasi tersebut baik atau tidak, menilai apakah obyek atau situasi tersebut baik atau tidak dan mengajukan suatu tindakan tertentu terhadapnya.

Afeksi ialah keadaan kuat atau lemahnya perasaan yang dipengaruhi oleh penerimaan dan penolakan terhadap obyek. Afeksi mengukur 
apakah sesuatu obyek itu disukai atau tidak. The feeling component of attitude refers to emotional connected with the object (Robert S. Fieldman, 2000:11). Kecenderungan berperilaku merupakan konsekuensi logis dari suatu keyakinan dan perasaan individu terhadap obyek. Bila seseorang yakin bahwa obyek itu baik, maka ia harus siap menerima obyek tersebut.

Pembentukan sikap tidak bisa disandarkan dan bukan kepribadian bawaan. Sikap terbentuk melalui proses belajar. Berbeda dengan hasil belajar yang lainnya, seperti perolehan suatu pengetahuan atau keterampilan yang dapat diperoleh dengan waktu yang singkat belajar, pembentukan sikap sangat rumit serta membutuhkan masa yang cukup panjang (Zakiah Daradjat, 1996:68).

Menurut Loudon dan Bitta dalam Zaim Elmubarok (2008:48), sumber pembentuk sikap ada empat, yakni pengalaman pribadi, interaksi dengan orang lain atau kelompok, pengaruh media massa dan pengaruh dari figure yang dianggap penting. Selanjutnya Swasta dan handoko dalam Zaim Elmubarok (2008:48), menambahkan bahwa tradisi, kebiasaan, kebudayaan dan tingkat pendidikan ikut mempengaruhi pembentuk sikap.

Dari beberapa pendapat di atas Azwar dalam Zaim Elmubarok (2008:48), menyimpulkan, faktor yang mempengaruhi pembentuk sikap adalah pengalaman pribadi, kebudayaan, orang lain yang dianggap penting, media massa, institusi atau lembaga pendidikan dan lembaga agama serta faktor emosi dalam diri seorang individu.

\section{Hakikat Agama}

Agama adalah kepercayaan kepada Tuhan yang selalu hidup, yakni kepada jiwa dan kehendak Ilahi yang mengatur alam semesta. Sedangkan menurut Herbert Spencer, agama adalah pengakuan bahwa segala sesuatu adalah manifestasi dari kuasa yang melampui pengetahuan kita, menurut CP. Tiele, pada hakikatnya agama adalah disposisi atau kerangka pikir yang murni dan luhur yang kita sebut sebagai kesalehan (Paul Edward Ed., 1996:160).

Dalam pandangan fungsionalisme, agama (religion atau religi) adalah satu sistem yang kompleks yang terdiri dari kepercayaan, keyakinan, sikap-sikap 
dan upacara-upacara yang menghubungkan individu dengan satu keberadaan wujud yang bersifat ketuhanan (JP. Chaplin, 2004:428). Durkheim juga memandang agama sebagai suatu kompleks sistem symbol yang memungkinkan terwujudnya kehidupan sosial dengan cara mengekspresikan dan memelihara sentiment-sentimen atau nilai-nilai dari masyarakat (Achmad Fedyani Saifudin, 2006:15). Menurut Durkheim agama harus mempunyai fungsi, karena agama bukan ilusi tetapi merupakan fakta social yang dapat diidentifikasi dan mempunyai kepentingan social (Syamsuddin Abdullah, 1997:31).

Dapat diambil kesimpulan sementara bahwa agama tidak hanya berurusan degan obyek-obyek yang bernilai tinggi, atau paling akhir bagi individu atau masyarakat tetapi juga dengan pemeliharaan dan pengembangan hidup dalam segala hal.

Menurut Harun Nasution (1995:11), unsur yang paling penting dalam agama adalah: percaya adanya kekuatan gaib. Manusia merasa dirinya lemah dan berhajat pada kekuatan gaib itu sebagai tempat

minta tolong. oleh karena itu, manusia merasa harus mengadakan hubungan baik dengan kekuatan gaib tersebut, mematuhi perintah dan larangan kekuatan gaib itu.

Sedangkan menurut Glock dan Stark yang dikutip oleh Robert $\mathrm{H}$. Thoules (2003:10), agama adalah sistem simbol, sistem keyakinan, sistem nilai, dan sistem perilaku yang terlembagakan yang semuanya berpusat pada persoalan-persoalan yang dihayati sebagai yang paling maknawi. Seluruh sistem tersebut berpusat pada satu konsep, yaitu ketuhanan. Maksudnya, agama merupakan sistem yang mengatur hubungan antara manusia dengan kekuatan adikodrati, yang dipandang sakral (suci atau kudus). Dalam terminologi agama, kekuatan adikodrati yang sakral itu disebut Tuhan. Dalam agama terdapat keyakinan manusia bahwa kesejahteraannya di dunia dan di akhrat tergantung pada adanya hubungan baik dengan kekuatan tersebut. Hubungan manusia dengan Tuhan lebih banyak berbentuk respon emosional yang beragam. Respon itu bisa mengambil bentuk perasaan takut, seperti yang terdapat dalam agama- 
agama primitive atau perasaan cinta sekaligus penyembahan seperti yang terdapat dalam agama-gama monoteisme. Bentuk-bentuk respon tersebut pada gilirannya akan menciptakan nilai yang menjadi dasar bagi cara hidup manusia beragama.

Keberagamaan bentuk respon manusia terhadap yang sakral dan keanekaan agama yang bisa dilacak pada setiap zaman, tempat, budaya dan peradaban menunjukkan bahwa manusia memiliki kecenderungan alamiah untuk percaya pada tuhan. Dalam Al Qur`an, kecenderungan alamiah itu disebut fitrah. Karena fitrah inilah, manusia pada dasarnya memiliki kebutuhan instrinsik untuk beragama. Dalam Al Qur`an surat ArRum ayat 30 Allah swt. berfirman yang artinya:

"Maka hadapkanlah wajahmu dengan lurus kepada agama Allah; (tetaplah atas) fitrah Allah yang telah menciptakan manusia menurut fitrah itu. tidak ada peubahan pada fitrah Allah. (Itulah) agama yang lurus; tetapi kebanyakan manusia tidak mengetahui".

Fitrah Allah, maksudnya ciptaan Allah swt. Manusia diciptakan Allah mempunyai naluri beragama yaitu agama tauhid kalau ada manusia tidak beragama tauhid, maka hal itu tidaklah wajar, mereka tidak beragama tauhid itu hanyalah lantaran pengaruh lingkungan.

Di dalam Al Qur`an ada dua terminologi agama, yaitu al-din, dan millah. Kata al-din terulang sebanyak 96 kali yang tersebar pada 44 surat, sedangkan kata millah sebanyak 15 kali yang tersebar pada 11 surat (Muhammad Fuad 'Abd Al Baqi, 199:329-330) kata al-din mempunyai banyak arti, antara lain ketundukkan, ketaatan, perhitungan, balasan, agama juga berarti bahwa seseorang bersikap tunduk dan taat serta akan diperhitungkan seluruh amalnya yang atas dasar itu ia memperoleh balasan dan ganjaran.

\section{Sikap Keberagamaan}

Agama dipeluk dan dihayati oleh manusia, praktek dan penghayatan agama tersebut diistilahkan sebagai keberagamaan (religiusitas).

Keberagamaannya, manusia menemukan dimensi terdalam dirinya yang menyentuh emosi dan jiwa. Oleh karena itu, keberagamaan yang baik akan membawa tiap individu memiliki jiwa yang sehat dan membentuk 
kepribadian yang kokoh dan seimbang.

Agama bersumber pada wahyu Tuhan. Oleh karena itu, keberagamaan pun merupakan perilaku yang bersumber langsung atau tidak langsung kepada wahyu Tuhan juga. Keberagamaan memiliki beberapa dimensi. Dimensi-dimensi tersebut antara lain dimensi pertama adalah aspek kognitif keberagamaan, dua dari yang terakhir adalah aspek behavioral keberagamaan dan yang terakhir adalah aspek afektif keberagamaan (Taufik Abdullah dan M. Rusli Karim, ed., 1989: 83).

Dalam bukunya American Piety: The Nature of Religion Commitmen, C.Y. Glock dan R. Stark menyebut ada lima dimensi agama dalam diri manusia, yakni dimensi keyakinan (ideologis), dimensi peribadatan atau praktek keagamaan (ritualistic), dimensi penghayatan (eksperensial), dimensi pengamalan (konsekuensial) dan dimensi pengetahuan agama (intelektual) (Djamluddin Ancok dan Fuat Nashori Suroro, 1995: 77).

Pertama, dimensi ideologis (ideological involvement). Berkenaan dengan seperangkat kepercayaan keagamaan yang memberikan penjelasan tentang Tuhan, alam manusia dan hubungan diantara mereka. Kepercayaan dapat berupa makna dari tujuan atau pengetahuan tentang perilaku yang baik yang dikehendaki Tuhan. Dimensi ini berisi pengakuan akan kebenaran doktrindoktrin dari agama. Seorang individu yang religius akan berpegang teguh pada ajaran teologis tertentu dan mengakui kebenaran doktrin agamanya, misalnya keyakinan akan adanya malaikat, surga-neraka dan sebagainya.

Kedua, dimensi intelektual (intellectual involvement) dapat mengacu pada pengetahuan tentang ajaran-ajaran agama, pada dimensi ini dapat diketahui tentang seberapa jauh tingkat pengetahuan agama (religiusliteracy) dan tingkat ketertarikan mempeserta didiki agama dari penganut agama, dalam dimensi ini bahwa orang-orang beragama paling tidak memiliki sejumlah pengetahuan mengenai dasar-dasar keyakinan, ritus-ritus kitab suci dan tradisi-tradisi.

Ketiga, dimensi eksperensial (experiencial involvement) adalah bagian keagamaan yang bersifat 
efektif, yakni keterlibatan emosional dan sentimental pada pelaksanaan ajaran (religion feeling). Dimensi ini berkaitan dengan pengalaman perasaan-perasaan, persepsi-persepsi dan sensasi-sensasi yang dialami seseorang atau didefinisikan oleh kelompok keagamaan saat melaksanakan ritual keagamaan. Seperti, tenteram saat berdoa, tersentuh mendengar ayat suci $\mathrm{Al}$ Qur`an dibacakan.

Keempat, dimensi ritualistic, (ritual involvement) merujuk pada ritus-ritus keagamaan yang dianjurkan dan dilaksanakan oleh penganut agama dan sangat berkaitan sekali dengan ketaatan penganut suatu agama. Dimensi ini meliputi pedoman pokok pelaksanaan ritus dan pelaksanaannya, frekuensi prosedur dan makna ritus penganut agama dalam kehidupan sehari-hari seperti penerapan rukun Islam, dzikir, shalat lima waktu dan lain-lain.

Kelima, dimensi konsekuensi atau dimensi sosial (consequential involvement) meliputi segala implikasi sosial dari pelaksanaan ajaran agama, dimensi ini memberikan gambaran apakah efek ajaran agama terhadap etos kerja, hubungan interpersonal, kepedulian kepada penderitaan orang lain dan sebagainya.

Sikap keberagamaan dalam perspektif Islam dijelaskan Al-Qur'an (2:208) di bawah ini:

"Hai orang-orang yang beriman, masuklah kamu ke dalam Islam keseluruhan, dan janganlah kamu turut langkahlangkah syaitan. Sesungguhnya syaitan itu musuh yang nyata bagimu”. (Q.S. Al Baqarah: 208).

Allah menuntut orang beriman (Islam) untuk beragama secara menyeluruh tidak hanya satu aspek atau dimensi tertentu saja, melainkan terjalin secara harmonis dan berkesinambungan. Oleh karena itu, setiap muslim baik dalam berfikir, bersikap maupun bertindak haruslah didasarkan pada nilai dan norma ajaran Islam.

Bagi seorang muslim, keberagamaan dapat dilihat dari seberapa dalam keyakinan, seberapa jauh pengetahuan, seberapa konsisten pelaksanaan ibadah ritual keagamaan, seberapa dalam penghayatan atas agama Islam serta seberapa jauh implikasi agama tercermin dalam perilakunya. Dalam Islam, keberagamaan akan lebih luas dan mendalam jika dapat dirasakan 
seberapa dalam penghayatan keagamaan seseorang.

Berdasarkan deskripsi di atas, dapat disimpulkan bahwa dimensi keberagamaan dalam Islam terdiri dari lima dimensi, yaitu: Aqidah (iman atau ideology), dimensi ibadah (ritual), dimensi amal (pengamalan), dimensi ihsan (penghayatan, situasi dimana seseorang merasa dekat dengan Allah), dan dimensi ilmu (pengetahuan).

Esensi Islam adalah tauhid, yaitu penegasan Allah sebagai pencipta yang mutlak dan transenden, penguasa segala yang ada. Tauhid adalah intisari Islam. Oleh Karena itu, suatu tindakan tidak dapat disebut bernilai Islam, jika tidak dilandasi oleh kepercayaannya kepada Allah SWT. Sejalan dengan pandangan Islam, Glock \& Stark menilai bahwa teologi adalah pusat keyakinan beragama. Teologi terdapat dalam seperangkat kepercayaan mengenai hari terakhir, mengenai alam dan kehendakkehendak supernatural, sehingga aspek-aspek lain dalam agama menjadi koheren. Ritual dan kegiatan yang menunjukkan ketaatannya baru dapat dipahami jika kegiatan-kegiatan tersebut berada dalam kerangka kepercayaan yang mengandung dalil bahwa ada suatu kekuatan yang besar yang harus disembah. Selain tauhid atau akidah, dalam Islam terdapat syariah dan akhlaq. Akidah adalah sistem kepercayaan dan dasar bagi syariah dan akhlaq. Syariah merupakan tatanan hukum, dan akhlaq adalah dimensi praktis dimana seseorang muslim berperilaku sesuai dengan norma dan nilai Islam.

Konsep keberagamaan Glock dan Stark mencoba melihat keberagamaan seseorang dengan memperhatikan semua dimensi. Untuk memahami keberagamaan umat Islam, diperlukan suatu konsep yang mampu memberikan penjelasan tentang beragam dimensi dalam Islam. Keberagamaan dalam Islam tidak hanya diwujudkan dalam bentuk ritual ibadah saja namun juga aktivitas lainnya. Sebagai sistem yang menyeluruh, Islam mendorong pemeluknya untuk beragama secara menyeluruh pula.

Dimensi keyakinan dapat disejajarkan dengan akidah, dimensi praktek agama disejajarkan dengan syariah, dan dimensi pengamalan disejajarkan dengan akhlaq. Dimensi keyakinan atau akidah Islam 
menunjuk pada seberapa jauh keyakinan seorang muslim terhadap kebenaran ajaran agamanya. Dalam Islam, isi dimensi keyakinan menyangkut keimanan terhadap Allah SWT, para malaikat, Nabi dan Rasul, kitab-kitab Allah, surga dan neraka, serta qada dan qadar-Nya.

Dimensi praktek agama atau syariah menunjuk pada seberapa jauh kepatuhan seorang muslim dalam mengerjakan kegiatan-kegiatan ritual sebagaimana diperintahkan oleh agama. Syariah adalah peraturanperaturan yang diciptakan pokokpokoknya agar manusia berpegang kepadanya dalam melakukan hubungan dengan Tuhan, dengan saudara sesama muslim, dengan saudara sesama manusia, dalam alam semesta dan dengan kehidupan. Dalam Islam, dimensi praktek agama atau peribadatan menyangkut pelaksanaan shalat, puasa, zakat, haji, membaca $\mathrm{Al}$ Qur`an, do`a, dzikir, ibadah, kurban dan ibadah-ibadah lainnya.

Dimensi pengamalan atau akhlaq menunjuk pada seberapa jauh seorang muslim berperilaku dan bersikap dengan motivasi yang bersumber dari ajaran agamanya. Dalam Islam, dimensi ini meliputi perilaku menolong, berderma, bekerja sama, menegakkan kebenaran dan keadilan, berlaku jujur, memaafkan, menjaga lingkungan, tidak mencuri, tidak menipu, tidak berjudi, tidak meminum-minuman yang memabukkan, dan mematuhi normanorma Islam.

Dimensi pengetahuan agama menunjuk pada seberapa jauh pengetahuan dan pemahaman seseorang muslim terhadap ajaranajaran agamanya. Dalam Islam, dimensi ini menyangkut pengetahuan tentang isi dan kandungan Al Qur`an, pokok-pokok ajaran Islam yang harus diimani dan hukum-hukum Islam, sejarah dan sebagainya.

Dimensi pengalaman atau penghayatan menunjuk pada seberapa jauh seorang muslim merasakan dan mengalami perasaan-perasaan dan pengalaman-pengalaman religius. Dalam Islam, dimensi ini terwujud dalam perasaan dekat dengan Allah, perasaan syukur yang mendalam, perasaan tenang dan damai dan sebaginya.

Dimensi-dimensi keberagamaan dalam Islam terdiri dari lima dimensi, yaitu: dimensi akidah (iman atau ideology), dimensi ibadah (ritual), dimensi amal (pengamalan), 
dimensi ihsan (penghayatan), dan dimensi ilmu pengetahuan (Djamluddin Ancok, Fuat Nashori Suroro, 1995: 79).

\section{Pertama, dimensi Akidah} (ideologi), dimensi ini mengungkap masalah keyakinan manusia terhadap rukun iman, kebenaran agama dan masalah-masalah gaib yang diajarkan agama. Seorang muslim yang religius memiliki ciri utama yang melekat berupa akidah yang kuat. Inti dimensi ini adalah tauhid yaitu peng-Esa-an Allah sebagai Yang maha Esa.

Kedua, dimensi ibadah (ritual), dimensi ini dapat diketahui dari sejauh mana kepatuhan seseorang dalam melaksanakan ibadah. Dimensi ini berkaitan dengan frekuensi, intensitas, pelaksanaan ibadah.

Ketiga, dimensi Amal (pengamalan), dimensi ini berkaitan dengan kegiatan seseorang dalam merealisasikan ajaran-ajaran agamanya dalam kehidupan yang diketahui dan perilaku yang positif dan yang konstruktif kepada orang lain yang dimotivasi oleh ajaran agama. Dimensi ini menyangkut hubungan antar manusia dan hubungan manusia dengan lingkungan alamnya. Dimensi ini dapat dimanifestasikan dengan berperilaku ramah dan baik terhadap orang lain, menolong, bertanggung jawab dan lain sebagainya.

Kempat, dimensi Ihsan (penghayatan), dimensi ini berkaitan dengan seberapa jauh seseorang merasa dekat dengan Allah swt. dalam kehidupannya. Dimensi ini mencakup pengalaman dan perasaan tentang kehadiran Allah SWT dalam kehidupan, ketenangan hidup, merasa khusyuk dalam ibadah, perasaan syukur atas segala karunia dan sebagainya.

Kelima, dimensi Ilmu (pengetahuan), dimensi ini berkaitan dengan pengetahuan dan pemahaman seseorang terhadap ajaran-ajaran agamanya mengenai dasar-dasar keyakinan, ritual-ritual, serta tradisitradisinya. Dan menjadikan Al Qur`an merupakan pedoman hidup religius sebagai sumber ilmu pengetahuan.

Dari pembahasan di atas, yang dimaksud dengan keberagamaan dalam penelitian ini adalah perilaku seseorang (peserta didik) yang didasarkan pada keyakinan, pengetahuan, ajaran-ajaran, aturanaturan dan norma-norma yang berlaku dan sesuai dengan agama Islam yang 
diterapkan dalam kehidupan seharihari.

Menurut Nur Ali dalam Muhaimin (2000: 300), mengemukakan bahwa penciptaan suasana keagamaan disekolah dapat dilakukan dengan cara pendekatan secara langsung. Yaitu dengan cara memberikan pengalaman dan pembiasaan melakukan khatmil qur'an, istighasah, shalat berjamaah, dan kegiatan-kegiatan keagamaan lainnya secara terprogram dan rutin pada waktu yang telah ditentukan.

Kegiatan keagamaan dan praktik keagamaan yang dilaksanakan secara terprogram dan rutin di sekolah dapat mentransformasikan dan menginternalisasikan nilai-nilai agama secara baik pada diri peserta didik. Sehingga agama menjadi sumber nilai dan pengangan dalam sikap berprilaku baik dalam setiap lingkugan.

Untuk mewujudkan sikap keberagamaan yang baik, selanjutnya menurut Muhaimin, dkk (2001:110), pendidikan agama Islam di sekolah umum akan berhasil dengan optimal dalam memberi "makna" dan "warna" serta menanamkan nilai-nilai fundamental bagi pembentukan sikap peserta didik kalau dibarengi dengan sikap proaktif dari guru agama serta adanya keterpaduan pembinaan. Sikap proaktif yang dimaksud adalah, bahwa seorang mampu keluar dari struktur, kondisi, dan aturan yang ada, untuk berusaha mencari jalan baru atau berada dalam perspektif "mengubah" sesuai dengan konteksnya.

\section{Pendidikan Anak Usia Dini}

Pendidikan Anak Usia Dini adalah suatu upaya yang dilakukan oleh orang dewasa untuk membina anak usia dini melalui pemberian rangsangan pendidikan untuk membantu tumbuh kembang jasmani dan rohani mulai anak dilahirkan hingga anak tersebut dianggap matang dalam memecahkan masalahnya supaya kelak anak tersebut memiliki kesiapan dalam menempuh pendidikan dasar dan kehidupan pada tahap-tahap selanjutnya.

\section{Mansur}

menyatakan Pendidikan Anak Usia Dini adalah suatu proses pembinaan tumbuh kembang anak usia lahir hingga enam tahun secara menyeluruh, yang mencakup aspek fisik dan motorik, dengan memberikan rangsangan bagi perkembangan 
jasmani, rohani (moral dan spiritual), motorik akal pikir, emosional dan sosial yang tepat agar anak dapat tumbuh dan berkembang secara optimal. Selanjutnya menurut Afia Rosdiana (2006:63) Pendidikan Anak Usia Dini sangat penting sebagai dasar meletakkan landasan bagi perkembangan hidup selanjutnya, maka dalam menanamkan konsepkonsep dan nilai-nilai pada anak harus sesuai dengan pola pertumbuhan dan perkembangannya. Kesalahan dalam menanamkan konsep pada masa tumbuh kembang anak usia dini akan berakibat fatal, sehingga pendidik perlu memahami dan menguasai tentang konsep Pendidikan Anak Usia Dini.

Beberapa pandangan yang dikemukakan diatas menunjukkan bahwa anak yang berada pada masa Golden Age memiliki kecendrungan untuk tumbuh dan berkembang secara fisik maupun mental akan lebih cepat. Supaya perkembangan fisik dan mental pada usia ini berkembang optimal maka peran dari keluarga, sekolah, dan masyarakat untuk mendukung perkembangan anak yaitu dapat direalisasikan dengan menyediakan dan mengkondisikan waktu, kesempatan dan sumberdaya yang dibutuhkan untuk perkembangan fisik dan mental anak perlu diutamakan. Dalam hal ini apapun yang dialami oleh anak pada usia ini diyakini memiliki efek kumulatif yang akan terbawa dan mempengaruhi perkembangan fisik dan mental anak selama menjalani kehidupannya.

Anak usia dini menurut National Assosiation in Education for Young Children (NAEYC) adalah anak yang berada pada rentang usia lahir sampai usia 8 tahun (Wikipedia, 2007). Anak usia dini memiliki potensi genetik dan siap untuk dikembangkan melalui pemberian berbagai rangsangan. Sehingga pembentukan perkembangan selanjutnya dari seorang anak sangat ditentukan pada masa awal perkembangan anak.

Sujiono (Dewi Salma dan Eveline Siregar; 2004:351) menjelaskan bahwa anak usia dini adalah sekelompok anak yang berusia 0-8 tahun yang memiliki berbagai potensi genetik dan siap untuk ditumbuh kembangkan melalui pemberian berbagai rangsangan. Banyak aspek-aspek perkembangan Anak Usia Dini (AUD), secara 
internasional sebenarnya aspek-aspek perkembangan AUD adalah:

1) Perkembangan fisik, baik motorik halus maupun motorik kasar.

Yang termasuk motorik halus adalah gerakan kaki dan yang termasuk dalam motorik kasar adalah langkah kaki anak saat berjalan maupun berlari.

2) Perkembangan emosional dan sosial.

Emosional berkaitan erat dengan segala hal yang berhubungan dengan perasaan anak, baik saat perasaan senang, kesal, gembira, sedih, dll. Sedangkan perkembangan sosial disini adalah interaksi anak baik dengan lingkungan, maupun orang-orang yang ada di sekitar keberadaan si anak.

3) Perkembangan

Kognitif/Intelektual

Perkembangan kognitif adalah perkembangan kemampuan anak untuk menggunakan bahasa.

\section{Internalisasi Sikap Keberagamaan untuk Anak Usia Dini}

Masalah penghayatan (internalitation) bukan hanya pada pendidikan agama saja, tetapi pada semua aspek pendidikan. Pendidikan akan menjadi dangkal jika hanya ditujukan untuk memperoleh ilmu (knowledge) terutama yang berkenaan dengan fakta (pengetahuan) dan kemahiran (skill). Pendidikan seperti ini tidaklah terlalu rumit karena tidak terlalu banyak melibatkan aspek nilai. Tetapi, sebaliknya pembelajaran sikap yang melibatkan nilai biasanya berasal dari cara kemasyarakatan yang diperoleh peserta didik semasa kecil.

Nilai itu mestinya mempunyai model, yang bermakna tempat nilai itu melekat supaya dapat disaksikan bagaimana nilai itu beroperasi. Ambillah sebuah nilai seperti kejujuran. Menurut Langgulung, nilai ini bersifat mujarrad (abstract). Supaya nilai yang bernama kejujuran itu dapat disaksikan beroperasi, maka nilai itu harus melekat pada suatu model, misalnya pada seorang guru, bapak, atau seorang kawan. Inilah sebagian yang perlu wujud untuk penghayatan nilai. Oleh karena pendidikan agama merupakan pendidikan ke arah penghayatan agama, maka orientasi pendidikan 
agama haruslah ditinjau kembali agar sesuai dengan tujuan tersebut (Hasan Langgulung, 2002: 234-235).

Pendidikan agama Islam yang dikemukakan oleh Hasan Langgulung. Mencerminkan bahwa pendidikan tak cukup dipeserta didiki secara teori saja. Pendidikan agama Islam harus bisa mengejawantahkan nilai-nilai ajaran Islam dalam kehidupan seharihari, kapan dan dimanapun. Pendidikan Islam harus menjadi spirit bagi manusia untuk mengembangkan SDMnya guna meraih kehidupan yang baik dan layak di dunia. Namun, pendidikan Islam juga harus menjadi pengontrol segala tindakan manusia agar dalam meraih tujuan hidup yang layak tersebut tetap dengan memegang teguh nilai-nilai Islam sehingga ia dapat mempertanggung-jawabkan tugas dan fungsi sebagai khalifah di muka bumi.

\section{Internalisasi} sikap keberagamaan yang harus diperkenalkan sejak dini dalam persprktif Islam, antara lain: pertama, sikap keberagamaan yang mengacu pada nilai keimanan. Pembinaan keimanan merupakan pembinaan yang pertama kali harus ditanamkan dalam jiwa dan pikiran anak sehingga pengembangan fitrah bagi manusia yang mempunyai sifat dan kecenderungan untuk mengakui dan mempercayai adanya Tuhan (Najib Khalid Al-Amir, 2002:145).

Anak usia dini lebih cenderung bersifat imitative, mengikuti apa yang dilakukan oleh orang dewasa. Oleh karena itu, keimanan merupakan nilai pertama yang harus ditanamkan untuk anak usia dini. Proses berfikir mereka juga masih dalam taraf berimajinasi. Dengan demikian, proses penanaman fitrah keimanan dapat terjaga dengan baik sejak dini.

Kedua, sikal keberagamaan dalam nilai ibadah. Penanaman nilai ibadah pada anak di mulai dari dalam keluarga. Karena anak usia dini lebih menyukai kegiatan-kegiatan ibadah yang nyata seperti melaksanakan sholat. Menurut Norma Tarazi (2003) dalam bukunya The Children Islam: A Muslim Parent's Handbook, orang tua harus mengingatkan anak untuk melakukan shalat secara terusmenerus. Jadi, kewajiban melaksanakan sholat itu harus diajarkan sejak dini, lebih baik lagi bila diajarkan pada anak usia dini mereka mulai diajarkan bacaan sholat dan gerakan sholat meskipun mereka 
belum berusia tujuh tahun tetapi pengenalan tentang ibadah sholat itu juga sangat penting.

Penanaman ibadah shalat ini dapat dilakukan pada pendidikan anak usia dini melalui kegiatan sebagai berikut (Wahyudi, 2005:42):

a. Guru membimbing anak untuk memper-siapkan sholat.

b. Guru memperkenalkan wudlu, pakaian bersih dan suci, mushola dan sebagainya.

c. Guru menjelaskan batasanbatasan aurat bagi laki-laki dan perempuan dalam sholat.

d. Anak mempraktekkan shalat berjamaah dalam kelompok kecil dan belajar untuk mengikuti imam.

e. Anak dilatih untuk tenang dan menjawab ketika mendengarkan adzan.

f. Anak dilatih untuk menghafalkan surat al-Fatihah.

g. Membiasakan anak untuk melaksanakan shalat tepat pada waktunya.

Ketiga, sikap keberagamaan dalam nilai akhlak. Menurut Nasiruddin (2010:31) adalah kata jamak dari kata khuluq. Kata khuluq adalah lawan dari kata khalq. Khuluq merupakan bentuk batin sedangkan khalq merupakan bentuk lahir. Akhlak adalah sesuatu yang telah tercipta atau terbentuk melalui sebuah proses. Karena sudah terbentuk akhlak disebut juga dengan kebiasaan. Dalam pengertian sehari-hari akhlak umumnya disamakan artinya dengan budi pekerti, kesusilaan, sopan-santun. Anak, sejak usia dini harus dibesarkan dengan bimbingan akhlak yang mulia dari orang tua dan dibesarkan dalam lingkungan yang kondusif, maka ia akan memiliki figur baik untuk diteladani dan membantu mereka dalam pembentukan pribadi yang Islami (Norma Tarazi, 2003:165). Akhlak pada anak terbentuk dengan meniru, bukan nasehat atau petunjuk. Anak selalu mengikuti tingkah laku orangtuanya. Maka diharapkan orang tua sebagai pendidik utama untuk lebih berhatihati dalam bertindak dan memberikan yang baik.

\section{Penutup}

Anak usia dini atau anak usia 0 hingga 6 tahun merupakan the golden age, karena pada masa ini berbagai kemampuan anak tumbuh dan berkembang sangat pesat peran 
guru/orang tua harus memaksimalkan potensi tersebut. Pemberian stimulasi dan fasilitas yang tepat pada masa ini, akan sangat berpengaruh pada proses perkembangan anak.

Anak dalam masa emas ini mampu tumbuh dan berkembang dengan pesat baik secara fisik, kognitif, emosi dan sosialnya. Pendidikan Anak Usia Dini mempunyai peranan penting untuk memenuhi kebutuhan perkembangan anak, termasuk kebutuhan akan keberagamaan. Internalisasi sikap keberagamaan dapat membantu untuk meningkatkan dan mengarahkan perkembangan anak usia dini tersebut. Internalisasi sikap keberagamaan terhadap anak usia dini bisa dimulai dari sikap keberagamaan yang ada dalam nilai keimanan kepada Allah SWT, sikap keberagamaan yang mengacu kepada nilai ibadah dan sikap keberagamaan yang terkandung dalam nilai akhlak. Internalisasi sikap keberagamaan sejak usia dini pada anak diharapkan akan menjadi bekal baginya di kemudian hari.

\section{Daftar Pustaka}

Azhar Arsyad. 2003. Media Pembelajaran. Jakarta: Rajawali Pers.
Chabib Thoha. 1996. Pendidikan Islam. Yogyakarta: Pustaka Pelajar

Direktorat PAUD dalam Haedari. 2009. Rencana Induk (Master Plan), Pendidikan Agama Islam Pada Pendidikan Anak Usia Dini (PAUD) 2010-2014 di Propinsi DKI Jakarta.

Direktorat Pendidikan Madrasah, Direktorat Jenderal Pendidikan Islam. 2011. Kurikulum RA/BA/TA. Pedoman Pengembangan Program Pembelajaran, Pedoman Pengembangan Silabus, Pedoman Penilaian, Kementerian Agama RI.

Dirjen PNFI. 2010. Pedoman Teknis Penyelenggaraan Kelompok Bermain. Kementerian Pendidikan Nasional: Jakarta.

http://repository.upi.edu/operato r/up load/tbp_999624_chapter1.pd f. Diunduh pada hari Kamis, tanggal 18 Juli 2017

http://repository.upi.edu/operato r/up load/tpendas_0808974_chapt er2.pdf. Diunduh pada hari Rabu, tanggal 17 Juli 2017.

http://alislamu.com/aqidah/683definisi-aqidah. $\mathrm{html}$. Diunduh pada hari Rabu, tanggal 17 juli 2017

Jasa Ungguh Muliawan. 2009. Manajemen Play Group dan Taman Kanak- kanak. Yogyakarta: DIVA Press

Kemenag. 2007. Peraturan Pemerintah Republik 
Indonesia Nomor 55 Tahun 2007 tentang Pendidikan Agama dan Pendidikan Keagamaan. Jakarta: Kementerian Agama

Kemendiknas. 2009. Peraturan Menteri Pendidikan Nasional Nomor 58 Tahun 2009 tentang Standar Pendidikan Anak Usia Dini. Jakarta: Kementerian Pendidikan Nasional

Kementerian Agama RI. 2011. Kurikulum RA/BA/TA. Direktorat Jenderal Pendidikan Islam. Direktorat Pendidikan Madrasah.

Murdiono, Mukhamad. 2009. Metode Penanaman Nilai Moral untuk Anak Usia Dini. Yogyakarta: Universitas Negeri Yokyakarta.

Permendiknas Nomor 58 Tahun 2009. Tentang Standar Pendidikan PAUD.

Rahim, Husni dkk. 2006. Kendali Mutu Pendidikan Agama Islam. Cet I. Departemen Agama RI. Direktorat Jenderal Pembinaan Kelembagaan Islam.

Rantina, Mahyumi. 2012. Pembelajaran Agama di Sentra Iman dan Taqwa Taman Kanak- Kanak Huffazh Payakumbuh. Jurnal Pesona PAUD Vol. 1 No. 1. Universitas Negeri Malang.

Syaiful Bahri Djamarah. 2000. Guru dan Anak Didik dalam Interaksi Edukatif. Jakarta: Rieneka Cipta
Tholkhah Hasan. 2009. Pendidikan Anak Usia Dini Dalam Keluarga. Jakarta: Mitra Abadi Press.

Trianto, 2010. Mendesain Model Pembelajaran InovatifProgresif. Cet II. Jakarta: Kecana Prenada Media Grup.

UU Nomor 20 Tahun 2003. Tentang Sistem Pendidikan Nasional Pasal 1 ayat 4.

Wahyu Nafilatul Azizah. 2009. Penanaman Nilai Agama Pada Anak di Taman Kanak-kanak (TK) Muslimat Nahdlatul Ulama (NU) 31 Sumbersari Malang. Surabaya: UNESA

Wikipedia. 2007. Early Chilhood Education. Diakses dari http://en.wikipedia.org/wiki/e arly_chilhood_education.

Pada tanggal 19 Juli 2017, jam 11.11 WIB

Yusuf al-Qardhawi. 1988. Ibadah dalam Islam. Surabaya: PT. Biru Ilmu 